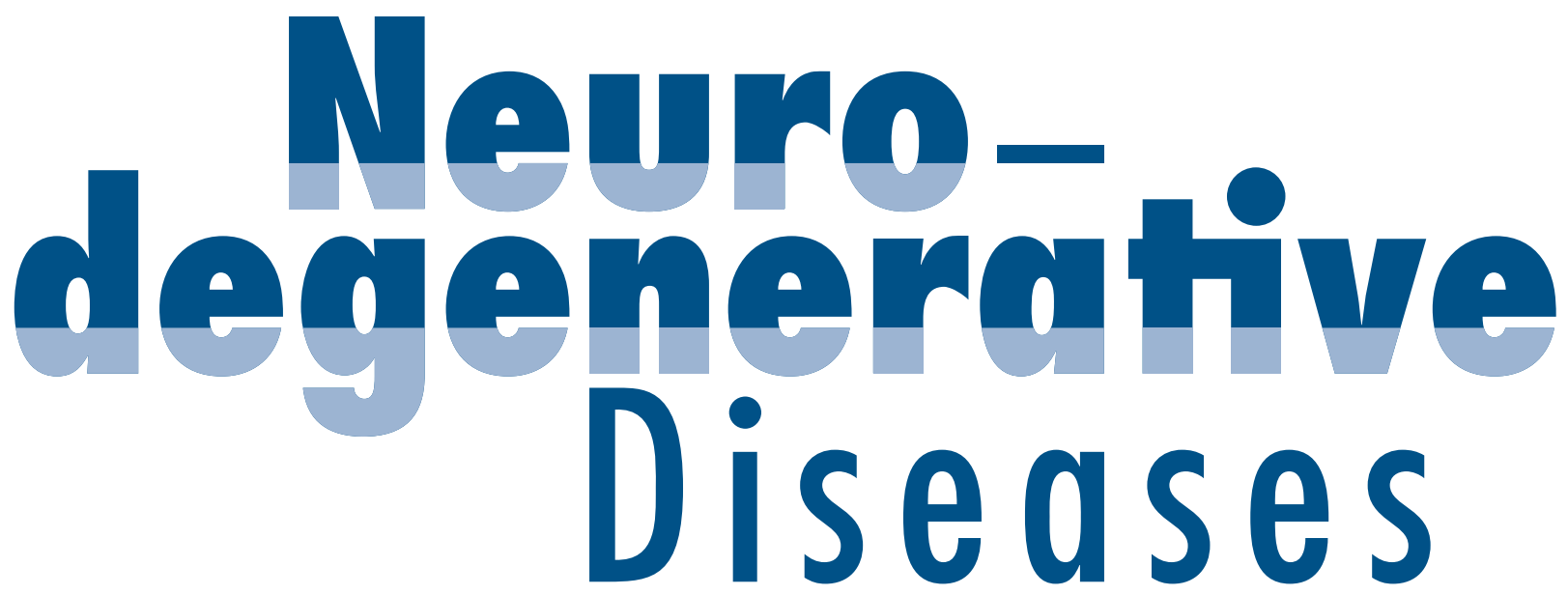

Original Papers

107 Intraspinal Injection of Human Umbilical Cord Blood-Derived Cells Is Neuroprotective in a Transgenic Mouse Model of Amyotrophic Lateral Sclerosis Knippenberg, S.; Thau, N.; Schwabe, K.; Dengler, R.; Schambach, A.; Hass, R.; Petri, S. (Hannover)

121 Optimal Plasma Progranulin Cutoff Value for Predicting Null Progranulin Mutations in Neurodegenerative Diseases: A Multicenter Italian Study

Ghidoni, R.; Stoppani, E. (Brescia); Rossi, G.; Piccoli, E. (Milan); Albertini, V.; Paterlini, A.; Glionna, M.; Pegoiani, E. (Brescia); Agnati, L.F. (Lido); Fenoglio, C.; Scarpini, E.; Galimberti, D.; Morbin, M.; Tagliavini, F. (Milan); Binetti, G.; Benussi, L. (Brescia)

128 Antiparkinsonian Mechanism of Electroconvulsive Therapy in MPTP-Lesioned Non-Human Primates Landau, A.M. (Aarhus/Vancouver, B.C.); Clark, C.; Jivan, S. (Vancouver, B.C.); Doudet, D.J. (Aarhus/Vancouver, B.C.)
139 Desmoplakin as a Potential Candidate for Cerebrospinal Fluid Marker to Rule Out 14-3-3 False Positive Rates in Sporadic Creutzfeldt-Jakob Disease Differential Diagnosis

Gawinecka, J.; Ciesielczyk, B. (Göttingen); Sanchez-Juan, P. (Santander); Schmitz, M.; Heinemann, U.; Zerr, I. (Göttingen)

145 N-Acetylcysteine Reverses Mitochondrial Dysfunctions and Behavioral Abnormalities in 3-Nitropropionic Acid-Induced Huntington's Disease

Sandhir, R.; Sood, A.; Mehrotra, A.; Kamboj, S.S. (Chandigarh)
S. Karger

Medical and Scientific Publishers Basel · Freiburg · Paris .

London · New York .

New Delhi · Bangkok · Beijing .

Tokyo $\cdot$ Kuala Lumpur .

Singapore Sydney KARGER

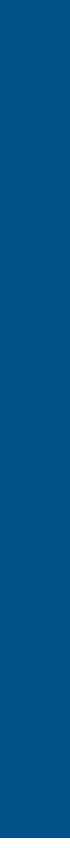




\title{
Psychiatry of Parkinson's Disease
}

\author{
Editors \\ Klaus Ebmeier \\ John T. O'Brien \\ John-Paul Taylor
}

Psychiatric symptoms are common in the neurological and geriatric care of patients with Parkinson's disease. This book assembles short reviews from experts in the field to chart the various psychiatric syndromes known in Parkinson's disease, their presentation, etiology and management. Presented are special topics on epidemiology of psychiatric symptoms, affective disorders and apathy, early cognitive impairment through to dementia, visuoperceptual dysfunction, psychotic disorders, sleep disturbances, impulse disorders and sexual problems. Further, rarely discussed issues, such as the relationship between somatoform disorders and parkinsonism are reviewed.

This publication is essential reading for old age psychiatrists, gerontologists and neurologists who work with patients suffering from Parkinson's disease. In addition, health practitioners who deal with senior patients, as well as scientists who need a quick update on the progress in this important clinical field will find this volume a helpful reference.

\section{Contents}

\section{Preface}

Epidemiology of Psychiatric Symptoms in Parkinson's Disease: Leentjens, A.F.G.

Depression, Apathy and Anxiety Disorders: Brockman, S.; Jayawardena, B.; Starkstein, S.E.

Apathy in Parkinson's Disease: Leroi, I.; David, R.; Robert, $P$.

Disorders of Visual Perception in Parkinson's Disease and Other Lewy Body Disorders: Collerton, D.; Mosimann, U.P.; Archibald, N.

Psychosis and Parkinson's Disease: Jakel, R.J.; Stacy, M.A.

Sleep in Parkinson's Disease and Dementia with Lewy Bodies: Ferman, T.J.; Boeve, B.F Sexual Problems in Parkinson's Disease: Sakakibara, R.; Uchiyama, T.; Yamamoto, T.; Kishi, M.; Ogawa, E.; Tateno, $F$.
An Update on Impulse Control Disorders in Parkinson's Disease: Voon, V.; Mehta, A.R.

Neuropsychological Features of Early Cognitive Impairment in Parkinson's Disease: Williams-Gray, C.H.; Mason, S.L.

Parkinson's Disease with Dementia: Taylor, J.-P.; O'Brien, J.T.

Somatoform Disorders in Parkinson's Disease and Dementia with Lewy: Bodies Evidence Underlying Psychotic Traits: Onofrj, M.; Thomas, A.; Bonanni, L.; di Giannantonio, M.; Gambi, F.; Sepede, $G$.

Drug-Induced Parkinsonism and Abnormal Involuntary Movements: Ritchie, C.W.
Fax: +41613061234

S. Karger AG, P.O. Box, CH-4009 Basel (Switzerland)

E-Mail orders@karger.ch, www.karger.com

Name/Address: 


\section{Editors-in-Chief}

R.M. Nitsch, Zürich

C. Hock, Zürich

\section{Associate Editor}

L. Rajendran, Zürich

\section{Section Editors}

\section{Modeling Neurodegenerative} Diseases in vivo

J.-P. Loeffler, Strasbourg

J.-L. Gonzalez de Aguilar, Strasbourg

\section{Clinical Drug Trial Section}

P. Herrling, Basel

V. Pogačić Kramp, Basel

\section{Editorial Board}

\section{Neurobiology}

Molecular Biology

K. Beyreuther, Heidelberg

R. Klein, Martinsried

M.S. Levine, Los Angeles, Calif.

B. Martoglio, Basel

S.S. Sisodia, Chicago, Ill.

E.E. Wanker, Berlin

Cell Biology

M.F. Beal, New York, N.Y.

A. Björklund, Lund

S. Gandy, New York, N.Y.

M. Goedert, Cambridge

C. Haass, München

K. Iqbal, Staten Island, N.Y.

T. Iwatsubo, Tokyo

E.H. Koo, San Diego, Calif.

G. Nikkhah, Freiburg

N.K. Robakis, New York, N.Y.

D.J. Selkoe, Boston, Mass.

G. Thinakaran, Chicago, Ill.

K. Unsicker, Freiburg

B. Wolozin, Maywood, Ill.

B.A. Yankner, Boston, Mass.

Animal Models

R. Baumeister, Freiburg

K. Duff, New York, N.Y.

D.L. Price, Baltimore, Md.

J. Shen, Boston, Mass.

O. von Bohlen und Halbach, Greifswald

Structural Biology

R. Glockshuber, Zürich

B. Solomon, Tel Aviv

C. Soto, Houston, Tex.

\section{Clinical Research}

Genetics

A. Brice, Paris

J. Hardy, Bethesda, Md.

L. Lannfelt, Uppsala

W. Le, Shanghai

H. Lehrach, Berlin

S. Lovestone, London

J. Mallet, Paris
E.I. Rogaev, Moskva

G.D. Schellenberg, Philadelphia, Pa.

C.E. Shaw, London

A. Singleton, Bethesda, Md.

P.H. St George-Hyslop, Toronto, Ont.

R.E. Tanzi, Boston, Mass.

C. Van Broeckhoven, Antwerpen

Neuropathology

A. Aguzzi, Zürich

B. Ghetti, Indianapolis, Ind.

C.L. Masters, Melbourne, Vic.

M.G. Spillantini, Cambridge

Imaging

N.C. Fox, London

R.S. Frackowiak, Lausanne

G.B. Frisoni, Brescia

A. Villringer, Berlin

Biological Markers

K. Blennow, Mölndal

T.N. Chase, Washington, D.C.

J. Ghika, Lausanne

J.H. Growdon, Boston, Mass.

Therapy

M. Bähr, Göttingen

S.T. DeKosky, Pittsburgh, Pa.

J. Dichgans, Tübingen

B. Dubois, Paris

W.H. Oertel, Marburg

M.N. Rossor, London

\section{Drug Discovery}

Biotechnology

P. Aebischer, Lausanne

D.B. Schenk, San Francisco, Calif.

Pharmaceuticals

K.M. Felsenstein, Spring House, Pa.

A. Fisher, Ness Ziona

L.L. Iversen, Oxford

J.A. Kemp, Hamburg

M. Miyamoto, Tokyo

H. Möhler, Zürich

B. Schmidt, Darmstadt

H. Soreq, Jerusalem

M. Takeda, Osaka

M.B.H. Youdim, Haifa
Printed in Switzerland on acid-free and non-aging paper (ISO 9706) by Reinhardt Druck, Basel
Appears bimonthly: 1 volume per year (6 issues) 


\section{Neirmo denenérätive Diseases}

'Neurodegenerative Diseases' is a bimonthly, multidisciplinary journal for the publication of advances in the understanding of 'Neurodegenerative Diseases', including Alzheimer disease, Parkinson's disease, amyotrophic lateral sclerosis, Huntington disease and related neurological and psychiatric disorders. 'Neurodegenerative Diseases' publishes results from basic and clinical scientific research programs designed to better understand the normal functions of genes and proteins involved in 'Neurodegenerative Diseases', to characterize their role in pathogenic disease mechanisms, to model their functions in animals and to explore their roles in the diagnosis, treatment and prevention of 'Neurodegenerative Diseases'. It is our firm belief that successful strategies for novel treatments of 'Neurodegenerative Diseases' will emerge from the intelligent integration of basic neurobiology with clinica sciences. Therefore, 'Neurodegenerative Diseases' will accept high-quality papers from a broad spectrum of scientific research areas ranging from molecular and cell biology to neuroscience, pharmacology, genetics and the clinical sciences.

'Neurodegenerative Diseases' is a peer-reviewed journal that publishes original research in the form of Articles and Brief Communications to 'Neurodegenerative Diseases' as well as Review Articles, Mini Reviews and Commentaries.

\section{Submission}

Only original papers written in English are considered and should be submitted online:

www.karger.com/ndd

Should you experience any problems with your submission, please contact:

\section{ndd@karger.ch}

Editorial Office 'Neurodegenerative Diseases' S. Karger AG

P.O. Box

CH-4009 Basel (Switzerland)

Tel. +41613061358

Fax +41613061434

Names, postal and e-mail addresses of four experts in the appropriate area of research should accompany each manuscript. Selected scientist(s) will be invited to act as referee(s). Referees suggested should not be from the same institution as the author and should have expert knowledge of the subject.

Articles should be fully documented reports of original research. They must describe significant and original observations to be critically evaluated and, if necessary, repeated. They do not normally exceed 6 printed pages including all figures, tables and references.

Brief Communications to Neurodegenerative Diseases are short reports of original research and are intended to provide a rapid means of reporting new findings of sufficient importance. They do not normally exceed 2 printed pages including an abstract, essential references and not more than 3 tables or figures.

Review Articles, Mini Reviews and Commentaries are either invited by the Editors or may be submitted for consideration. Authors who wish to contribute a manuscript to one of these categories should contact the Editor-in-Chief.
Review Articles describe new developments of interdisciplinary significance and highlight unresolved questions and future directions. They do not generally occupy more than 9 printed pages. Mini Reviews should focus on topics of current interest and not exceed 5 printed pages.

Commentaries should offer a more personalized per spective on a topic that will be of interest to the general readership and fill an integral number of printed pages, generally one or two, including one or two small figures. All contributions to these categories will be subjected to editorial review.

Reports should comprise title page, Key Words, Abstract, Introduction, Results and Discussion, References, tables, figure legends, and figures - in this order.

\section{Special Section:}

\section{Modeling Neurodegenerative Diseases in vivo}

Editorial policies and guidelines for submission to this section are as those given for the prime section of 'Neurodegenerative Diseases', except that the editorial responsibility falls within the province of the section editors Jean-Philippe Loeffler and José-Luis Gonzalez de Aguilar, Strasbourg. Contributions should be submitted online:

\section{www.karger.com/ndd}

Please mention in your convering letter that your article is submitted for publication in 'Modeling Neurodegenerative Diseases in vivo'

\section{Conditions}

Only manuscripts that conform to the Guidelines for Authors will be considered and are subject to editorial review.

The manuscript must be accompanied by a cover letter stating that all authors have seen and given their approval for submission of the manuscript to be considered for publication in 'Neurodegenerative Diseases' Manuscripts are accepted for review with the understanding that persons cited in unpublished work have approved such citations. Authors may provide the names and contact information for three or four suggested reviewers for their papers.

Manuscripts are received with the explicit understanding that they are not under simultaneous consideration by any other publication or have not already been published elsewhere. Submission of an article for publication implies transfer of the copyright from the author to the publisher upon acceptance. Accepted papers become the permanent property of 'Neurodegenerative Diseases' and may not be reproduced by any means, in whole or in part, without the written consent of the publisher. It is the author's responsibility to obtain permission to reproduce illustrations, tables, etc. from other publications.

The authors agree that their articles will be accompanied, if necessary, by a simplified version written by a scientific writer.

Manuscripts that do not comply with the ethical standards recommended by the Helsinki Declaration will not be accepted.

\section{Arrangement}

Title page: The first page of each paper should indicate the title, the authors' names, the institute where the work was conducted, and a short title for use as running head.

Full address: The exact postal address of the corresponding author complete with postal code must be given at the bottom of the title page. Please also supply phone/fax numbers and e-mail address.

Key words: Please supply 3-10 key words in English that reflect the content of the paper.

Abstract: Each paper needs an abstract of about 200 words, and should be structured as follows:

Background: What prompted the study?

Objective: What is the purpose of the study?

Methods: How was the study carried out?

Results: What are the most important findings?

Conclusion: What is the most important conclusion?

The abstract should not exceed 250 words, and any abbreviations must be explained.

Footnotes: Avoid footnotes. When essential, they should be numbered consecutively and typed at the foot of the appropriate page.

Tables and illustrations: Tables and illustrations (both numbered in Arabic numerals) should be prepared on separate sheets. Tables require a heading and figure legends should be supplied on a separate sheet. For the reproduction of illustrations, only good drawings and original photographs will be accepted; negatives or photocopies cannot be used. Due to technical reasons, figures with a screen background should not be submitted. When possible, group several illustrations in one block for reproduction (max. size $180 \times 223 \mathrm{~mm}$ ) or provide crop marks. Electronically submitted b/w halftone and color illustrations must have a final resolution of $300 \mathrm{dpi}$ after scaling, and line drawings one of 800 $1,200 \mathrm{dpi}$.

\section{Color illustrations}

Online edition: Color illustrations are reproduced free of charge. In the print version, the illustrations are reproduced in black and white. Please avoid referring to the colors in the text and figure legends.

Print edition: Up to 6 color illustrations per page can be integrated within the text at CHF 800.- per page.

References: Identify references in the text with Arabic numerals [in square brackets]. Material submitted for publication but not yet accepted should be noted as 'unpublished data' and not be included in the reference list. The list of references should include only those publications cited in the text. Do not alphabetize; number references in the order in which they are first mentioned in the text. The surnames of the authors followed by their initials should be given. There should be no punctuation other than a comma to separate the authors. Preferably, please cite all authors. Abbreviate journal names according to the Index Medicus system. Also see International Committee of Medical Journal Editors: Uniform requirements for manuscripts submitted to biomedical journals (www.icmje.org).

\section{KARGER}

Fax +4161306 1234

E-Mail karger@karger.ch

www.karger.com 
Examples

(a) Papers published in periodicals: Desai MY, De la Peña-Almaguer E, Mannting F: Abnormal heart rate recovery after exercise: A comparison with known indicators of increased mortality. Cardiology 2001;96: $38-44$.

(b) Papers published only with DOI numbers:

Theoharides TC, Boucher W, Spear K: Serum interleukin-6 reflects disease severity and osteoporosis in mastocytosis patients. Int Arch Allergy Immunol DOI: $10.1159 / 000063858$.

(c) Books: Matheis G, Moritz A, Scholz M (eds): Leukocyte Depletion in Cardiac Surgery and Cardiology. Basel, Karger, 2002

(d) Edited books: Gladish GW, Haponik EF: Virtual Bronchoscopy; in Bolliger CT, Mathur PM (eds): Interventional Bronchoscopy. Prog Respir Res. Basel Karger, 2000, vol 30, pp 253-266.

Papers that have been submitted but are not yet accepted should not be listed in the bibliography, but can be referred to in the text as unpublished observations. If details of methods are only available in papers that are 'in press', copies of the papers should be included with the manuscript submitted to 'Neurodegenerative Diseases' so that the editorial referees can have adequate information to judge the manuscript.

Reference Management Software: Use of EndNote is recommended for easy management and formatting of $\mathrm{ci}$ tations and reference lists.

Digital Object Identifier (DOI)

S. Karger Publishers supports DOIs as unique identifiers for articles. A DOI number will be printed on the title page of each article. DOIs can be useful in the future for identifying and citing articles published online without volume or issue information. More information can be found at www.doi.org.

\section{Supplementary Materia}

Supplementary material is restricted to additional data that are not necessary for the scientific integrity and conclusions of the paper. Please note that all supplementary files will undergo editorial review and should be submitted together with the original manuscript The Editors reserve the right to limit the scope and length of the supplementary material. Supplementary material must meet production quality standards for
Web publication without the need for any modification or editing. In general, supplementary files should not exceed $10 \mathrm{MB}$ in size. All figures and tables should have titles and legends and all files should be supplied separately and named clearly. Acceptable files and formats are: Word or PDF files, Excel spreadsheets (only if the data cannot be converted properly to a PDF file), and video files (.mov, .avi, .mpeg)

\section{Drugs}

Generic names should be used in text, tables, and figures. Trade names in upper case may be mentioned in parentheses in the first text reference to the drug but should not appear in titles, figures or tables. The chemical nature of new drugs must be given when known.

\section{Abbreviations}

When an abbreviation is used in the manuscript, it should be defined in the text the first time it is used. Abbreviations for commonly used substances should be those recommended by the Journal of Biological Chemistry. Abbreviations for drugs/chemicals may be used if properly defined with the chemical or generic name when the abbreviation is first used. Excessive use of abbreviations in the text, however, is strongly discouraged. Most abbreviations are used without punctuation, with no distinction between singular and plural forms.

\section{Author's Choice ${ }^{\mathrm{TM}}$}

With this option the author can choose to make his article freely available online against a one-time fee of CHF 3000.-. This fee is independent of any standard charges for supplementary pages, color images etc. which may apply. More information can be found at www.karger.com/authors_choice.

\section{NIH-Funded Research}

The U.S. National Institutes of Health (NIH) mandates under the NIH Public Access Policy that final, peerreviewed manuscripts appear in its digital database within 12 months of the official publication date. As a service to authors, Karger submits the final version of your article on your behalf to PubMed Central (PMC) immediately upon publishing. It usually receives a PMCID within approximately a month and will appear in PMC after 12 months. For those selecting our premium Author's Choice ${ }^{\mathrm{TM}}$ service, the usual embargo will be overriden, accelerating the accessibility of your work. More details on NIH's Public Access Policy are available at http://publicaccess.nih.gov/policy.htm

\section{Self-Archiving}

Karger permits authors to archive their pre-prints (i.e. pre-refereeing) or post-prints (i.e. final draft post-refereeing) on their personal or institution's servers, provided the following conditions are met: Articles may not be used for commercial purposes, must be linked to the publisher's version, and must acknowledge the publisher's copyright. Authors selecting Karger's Author's Choice ${ }^{\mathrm{TM}}$ feature, however, are also permitted to archive the final, published version of their article, which includes copyediting and design improvements as well as citation links.

\section{Page Charges}

There is no page charge for papers of 5 or fewer printed pages (including tables, illustrations and references). Each additional complete or partial page is charged to the author at CHF 325.-. The allotted size of a paper is equal to approx. 14 manuscript pages (including tables, illustrations and references).

\section{E-pub First}

All articles are published electronically ahead of print with a DOI number and are supplemented later with the definite reference of the printed version. The articles become available immediately after the authors' approval to publication, with the added advantage of being citable much earlier than previously. Authors can influence the time of appearance by promptly returning the proofs.

\section{Proofs}

Unless otherwise indicated, proofs are sent to the corresponding author and should be returned with the least possible delay. Alterations other than the correction of printer's errors are charged to the author.

\section{Reprints}

Order forms and a price list will be sent with the proofs. Orders submitted after the issue is printed are subject to considerably higher prices.

\section{KARGER}

\section{(C) 2012 S. Karger AG, Base}




\section{Newro derenerative Diseases}

ISSN Print Edition: 1660-2854 ISSN Online Edition: 1660-2862

Journal Homepage: www.karger.com/neurodis

Publication Data: 'Neurodegenerative Diseases' is published 8 times a year. Volumes 9 and 10, with 4 issues each, appear in 2012

Copyright: (c) 2012 S. Karger AG, Basel (Switzerland) All rights reserved. No part of this publication may be translated into other languages, reproduced or utilized in any form or by any means, electronic or mechanical, including photocopying, recording, microcopying, or by any information storage and retrieval system, with out permission in writing from the publisher or, in the case of photocopying, direct payment of a specified fee to the Copyright Clearance Center.

Disclaimer: The statements, opinions and data contained in this publication are solely those of the individual authors and contributors and not of the publisher and the editor(s). The appearance of advertisements in the journal is not a warranty, endorsement, or approval of the products or services advertised or of their effectiveness, quality or safety. The publisher and the editor(s) disclaim responsibility for any injury to persons or property resulting from any ideas, methods, instructions or products referred to in the content or advertisements.
Subscription Rates: Subscriptions run for a full calendar year. Prices are given per year. Personal subscription:

Print or Online

CHF 495.-

EUR 396--

USD 481.00

Print+Online combined

EUR 472

USD 575.00

postage and handling (added to print and print+online)

CHF 54.40 Europe, CHF 58.50 Overseas

EUR 41.60

USD 75.20

Institutional subscription:

Print or Online

Print+Online combined

CHF 1650.

EUR 1320.-

CHF 1816.-

postage and handling (added to print and print+online)

CHF 68.- Europe, CHF 100.- Overseas

EUR 52.-

USD 94.00

Airmail surcharge: CHF 68.- / USD 64.00
Back Volumes and Single Issues: Information on availability and prices of single print issues and print or electronic back volumes can be obtained from Customer Service at service@karger.ch.

Bibliographic Indices: This journal is regularly listed in bibliographic services, including Current Contents ${ }^{\circledR}$ and PubMed/MEDLINE.

Photocopying: This journal has been registered with the Copyright Clearance Center (CCC), as indicated by the code appearing on the first page of each article. For readers in the US, this code signals consent for copying of articles for personal or internal use, or for the personal or internal use of specific clients, provided that the stated fee is paid per copy directly to

Copyright Clearance Center Inc.

222 Rosewood Drive

Danvers, MA 01923 (USA)

A copy of the first page of the article must accompany payment. Consent does not extend to copying for general distribution, for promotion, for creating new works, or for resale. In these cases, specific written permission must be obtained from the copyright owner,

S. Karger AG, P.O. Box

CH-4009 Basel (Switzerland).
Subscription Orders:

Orders can be placed at agencies,

bookstores, directly with the Publisher

\section{S. Karger AG}

Medical and Scientific Publishers

P.O. Box

$\mathrm{CH}-4009$ Basel

Switzerland

(for courier services only:

Allschwilerstrasse 10

$\mathrm{CH}-4055$ Basel)

t: +41613061111

f: +41613061234

e: karger@karger.ch

w: www.karger.com or further Karger offices

or representatives:

Germany

S. Karger GmbH

Postfach

79095 Freiburg

Deutschland

(Hausadresse: Wilhelmstrasse 20A,

79098 Freiburg)

$\mathrm{t}: \quad+49761452070$

f: $\quad+497614520714$

e: information@karger.de

w: www.karger.de

\section{Japan}

Karger Japan, Inc

Shiba Daimon Asahi Bldg. 2F

1-2-23 Shiba Daimon

Minato-ku

Tokyo 105-0012

Japan

$\mathrm{t}:+81364356242$

f: +81364356244

e: publisher@karger.jp

w: www.karger.jp

Change of Address:

Both old and new address should be sent to the subscription source.

USA

S. Karger Publishers, Inc.

26 West Avon Road

P.O. Box 529

Unionville, CT 06085

USA

Toll free: +18008285479

t: +18606757834

f: +18606757302

e: karger@snet.net

France

Librairie Médi-Sciences Sar

36, bd de Latour-Maubourg

75007 Paris

France

: $+33(0) 145514258$

f: $+33(0) 145560780$

e: librairie@medi-sciences.fr

w: www.medi-sciences.fr

Gulf Council Countries, Iran,

Middle East, North Africa, Turkey

Trans Middle East International

Distribution Co. Ltd.

KaSha

134 Queen Rania Al Abdullah Street

Jordan Trade Center Bldg. 3rd Floor

P.O. Box 2376

Amman 11953

Jordan

t: +96265153467

f: +96265153472

e: info@kasha.cc

w: www.KaShaonline.com
South East Asia, China and Taiwan Karger Regional Office (Malaysia) CEO Suite Kuala Lumpur Quill 7, 27th Floor

Jalan Stesen Sentral 5

KL Sentral

Kuala Lumpur 50470

Malaysia

t: +60327766803

f. +60327766999

e: service@karger.cn; r.chew@karger.cn

\section{Karger China}

10th Floor, Twin Towers (East)

B12 Jianguomenwai Avenue

Beijing 100022

China

$\mathrm{t}:+861051235033$

f: +861051235122

e: service@karger.cn; r.chew@karger.cn

w: www.karger.cn

India, Bangladesh, Sri Lanka

Medscience India

Plot No. 17, Yusuf Sarai Market

B.L. Glass Building, 2nd Floor

Sri Aurobindo Marg

New Delhi 110016

India

t: +911146029633

f: +911146029634

c: +919891052128

e: medsci.india@gmail.com

\section{KARGER}

Fax +4161306 1234

E-Mail karger@karger.ch

www.karger.com

\section{(c) 2012 S. Karger AG, Base}

The Journal Home Page is available at:

www.karger.com/neurodis 


\section{Contents}

See the journal website for contents 


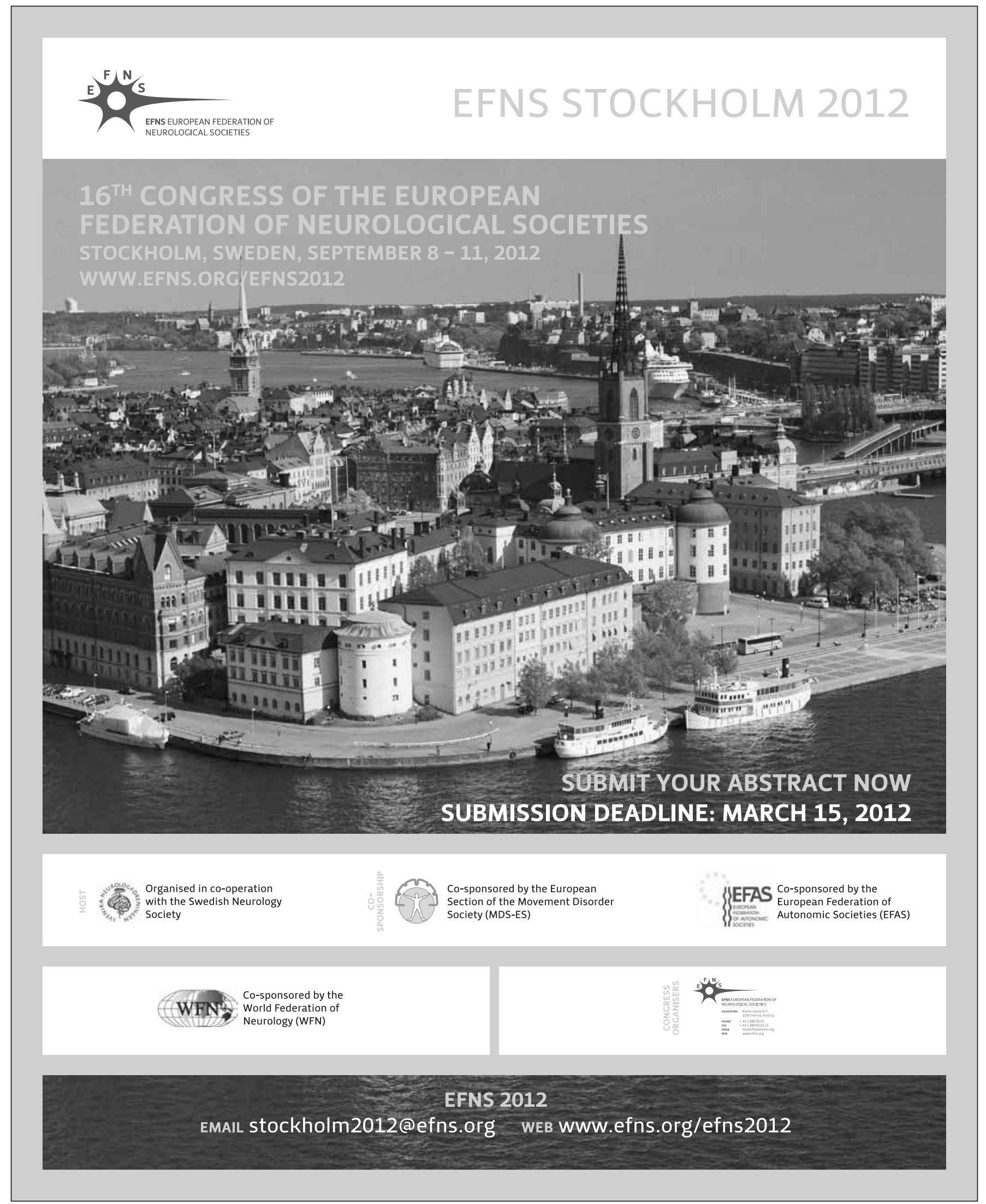


Alzheimer's Association International Conference 2012

July 14-19

Vancouver, British Columbia

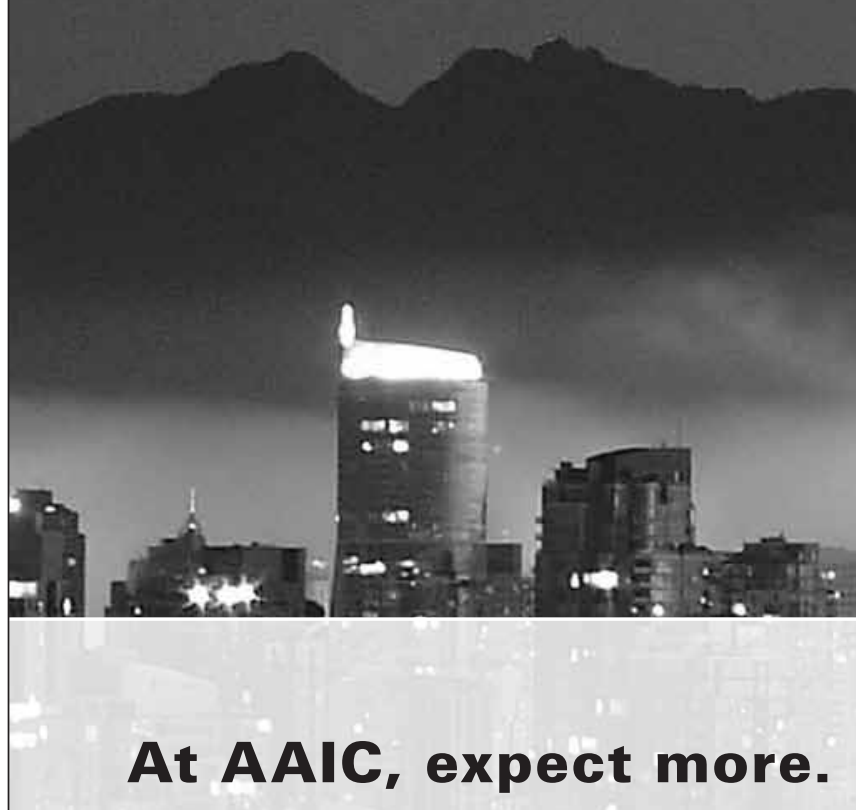

Register for AAIC 2012 to join the world's leading scientists in a unique forum where you can expect more. More opportunities to learn. More opportunities to share. And more opportunities to advance dementia research.
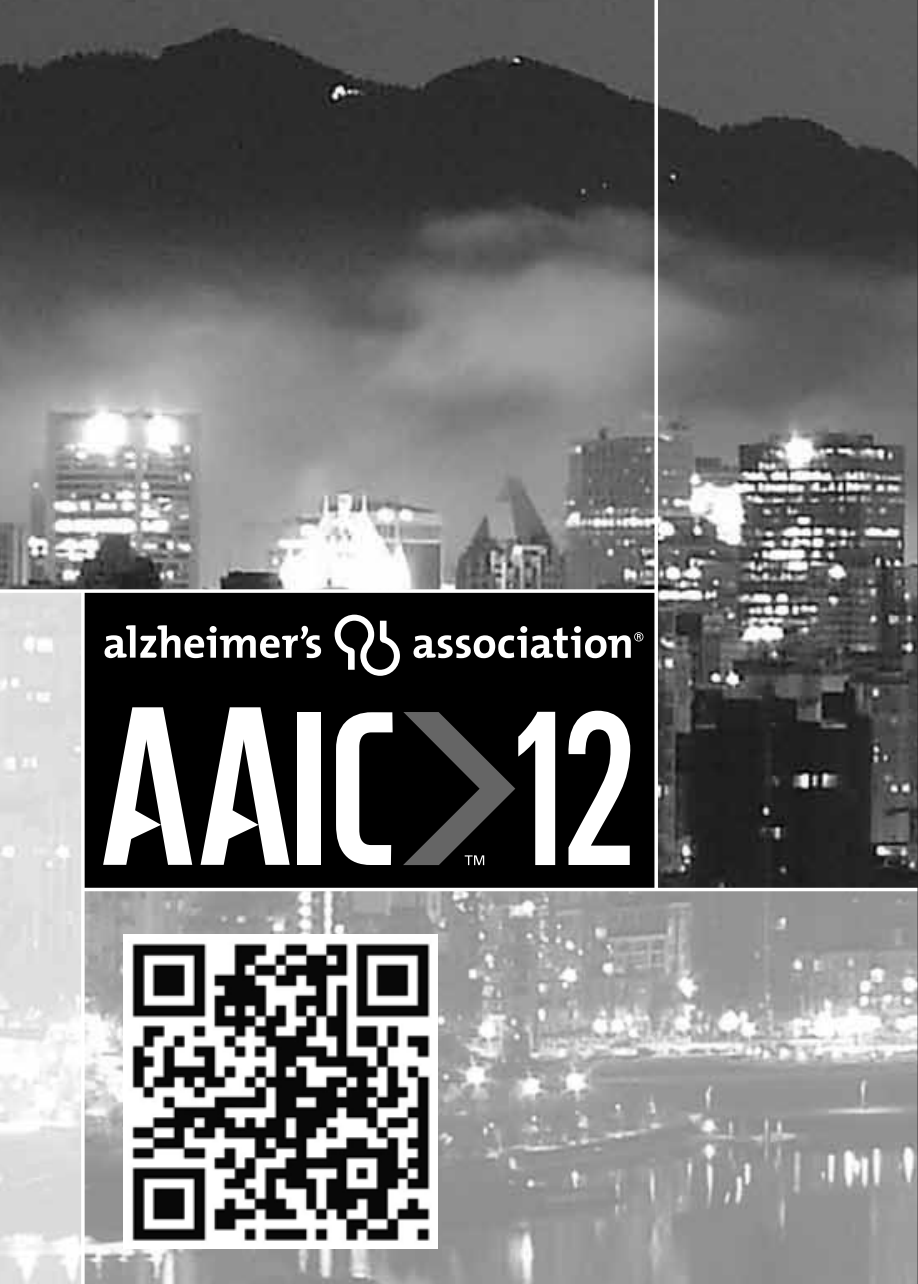

alz.org/AAIC

alzheimer's $\Omega$ association

Vancouver Skyline 


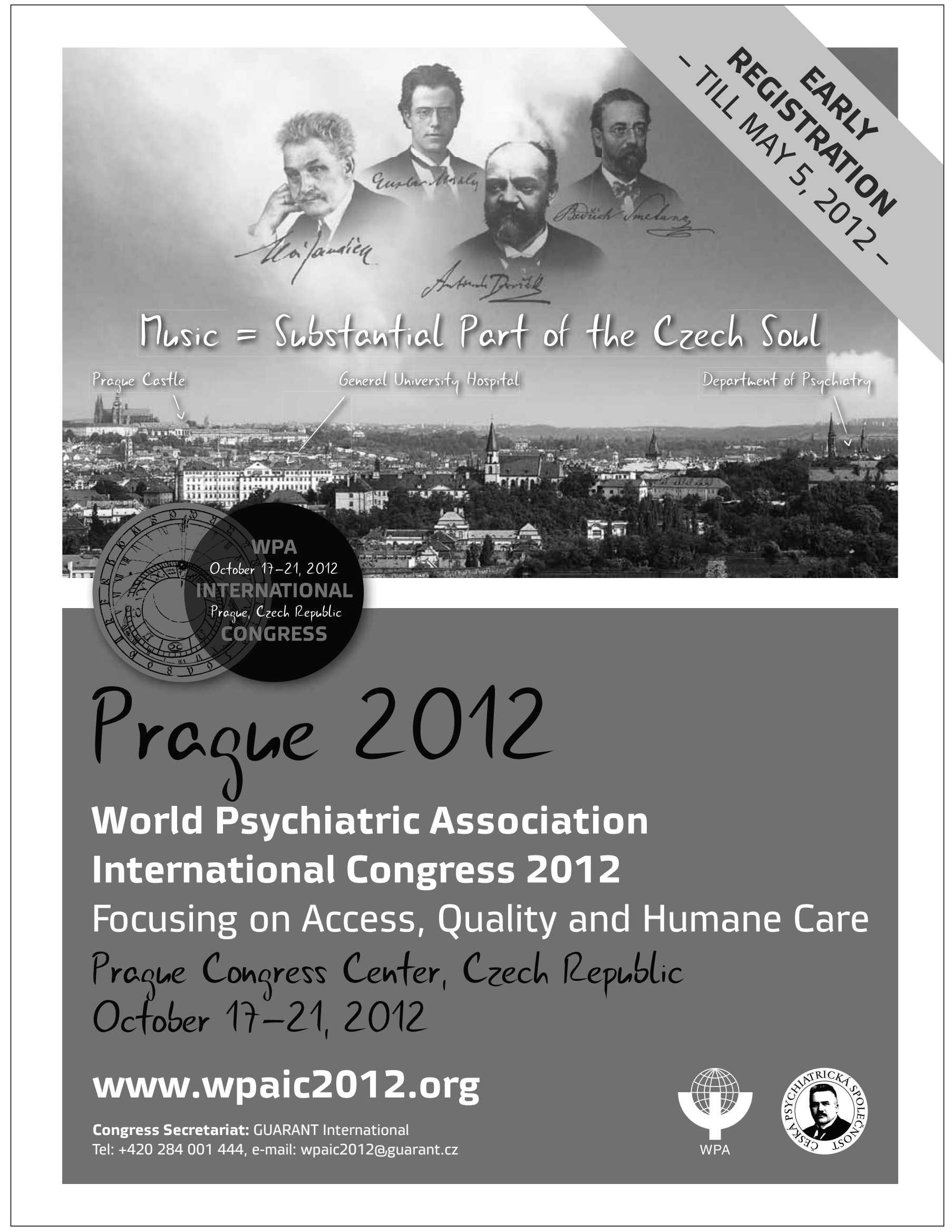




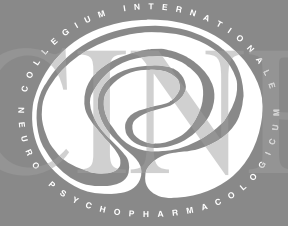

\section{8th CINP WORLD CONGRESS OF NEUROPSYCHOPHARMACOLOGY}

CINP - The International College of Neuropsychopharmacology

\section{3-7 June 2012 Stockholm Sweden}

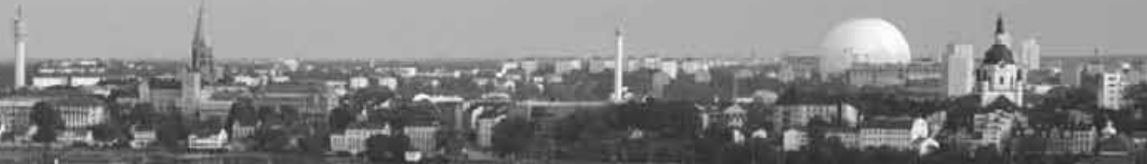

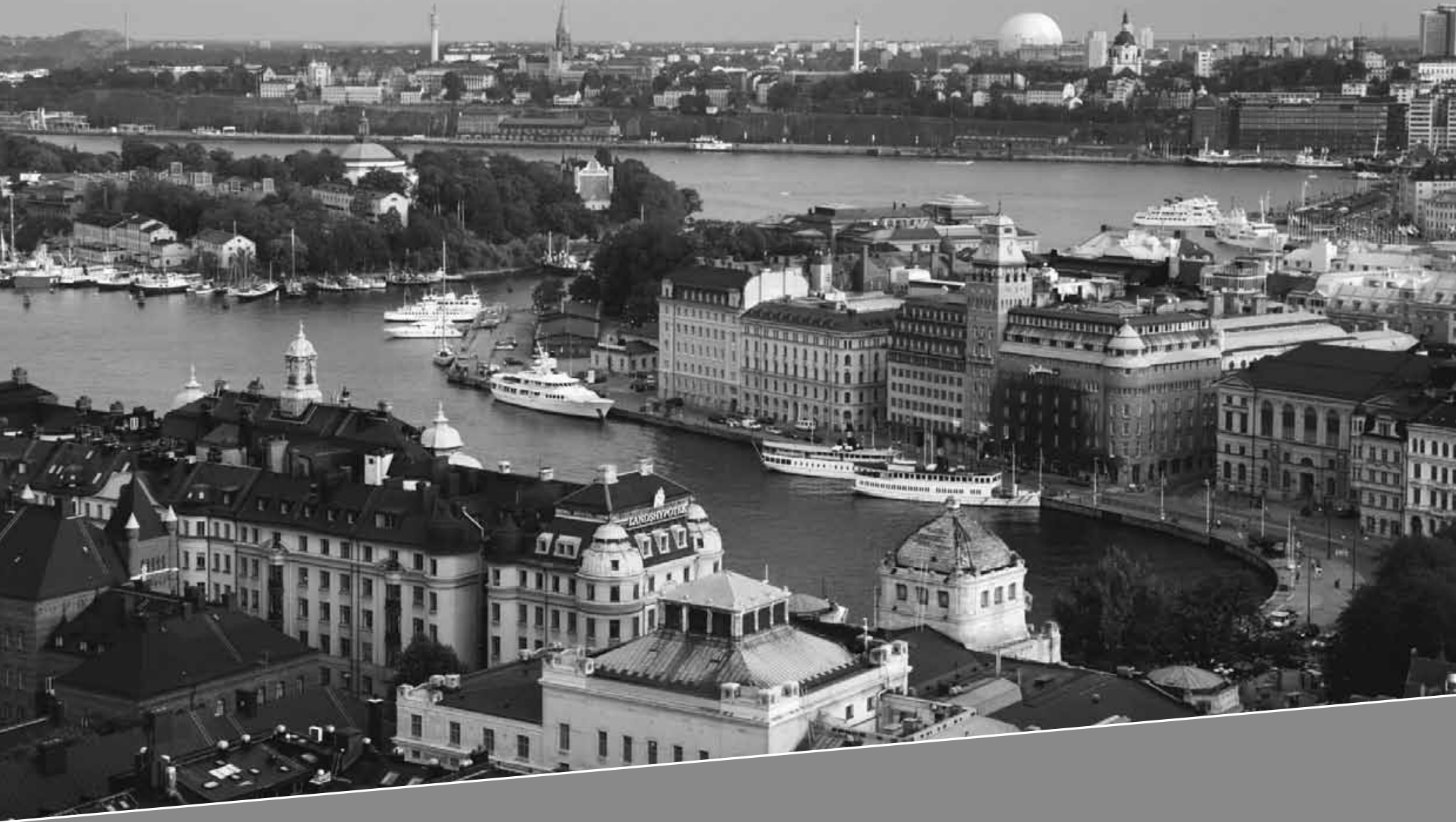




\section{Call for Abstracts}

International Society for Neurochemistry \&

American Society for Neurochemistry 24th Joint Meeting

Cancun, Mexico, April 20 - 24, 2013

On-line Abstract Submissions Deadline: October 15, 2012

www.ISN-ASNcancun2013.org
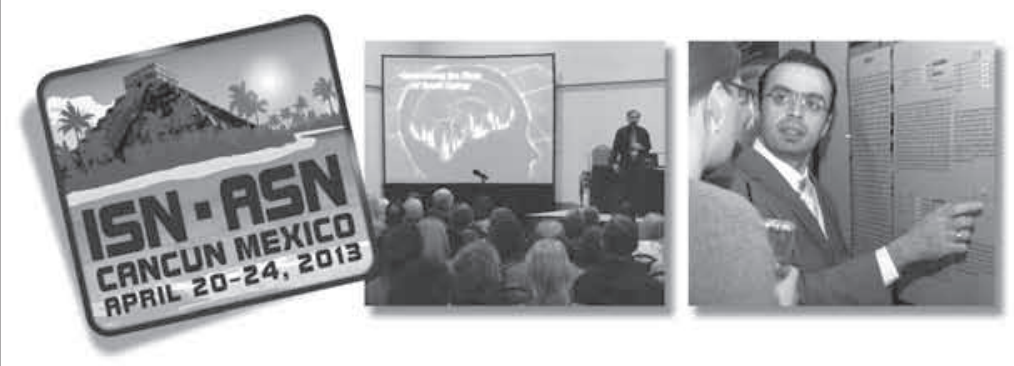

Join us for four days of symposia, colloquia and workshops designed to address the four major themes of our Society:

- Building the Nervous System

- Glial Cell Biology

- Molecular and Cell Biology of the Nervous System

- Neurodegeneration and Disease
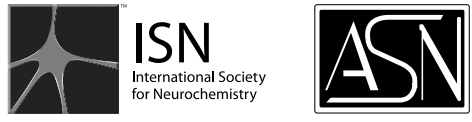

www.ISN-ASNcancun2013.org

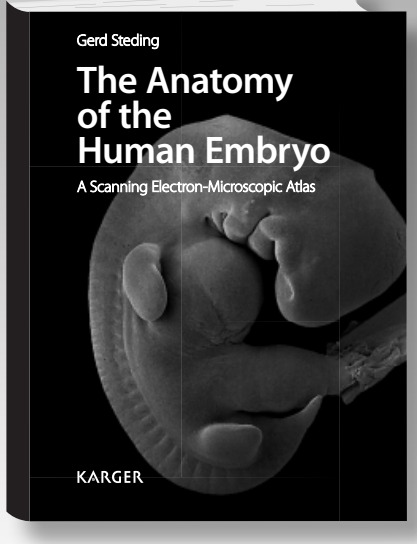

Steding, G. (Göttingen)

The Anatomy of the Human Embryo A Scanning Electron-Microscopic Atlas

XIV + 516 p., 818 fig., soft cover, 2009

CHF 246.- / EUR 182. - / USD 246.00

ISBN 978-3-8055-9705-0

e-ISBN 978-3-8055-9706-7

$\stackrel{0}{\rightleftarrows}$ Prices subject to change

E $\quad$ EUR price for Germany, USD price for USA only
Outstanding pictures providing precious insights into prenatal human development

\section{Gerd Steding The Anatomy of the Human Embryo A Scanning Electron-Microscopic Atlas}

The present anatomical atlas concentrates on the early weeks of prenatal development of the human embryo. It comprises more than 800 scanning electron-microscopic pictures of specimens of exclusively human embryos. The three-dimensional appearing illustrations show the development of the external form of the face, neck, trunk and limbs. Besides, the brain and the viscera of the head, neck, thorax, abdomen and pelvis - all dissected into layers - are represented in their position and spatial form.

The juxtaposition of pictures of temporally close developmental stages reveals the changes in the form of the organs. Photographs of the same organic system are usually shown at the same magnification. Simple outline drawings provided with the principal nomenclature facilitate the orientation within the specimens. A brief introduction to each chapter explains the most significant developmental steps depicted.

This atlas is of great interest not only to anatomists, embryologists, histologists and developmental biologists, but also to biologists, biochemists and geneticists. Moreover, it serves as a valuable reference book for clinicians such as gynecologists, obstetricians, pediatric surgeons and pediatric cardiologists.

www.karger.com/anat-humanembryo 


\section{NeuroImmunoWodulation}

Official Journal of the International Society for Neuroimmunomodulation
Editor-in-Chief

W. Savino, Rio de Janeiro

Associate Editor

A. del Rey, Marburg

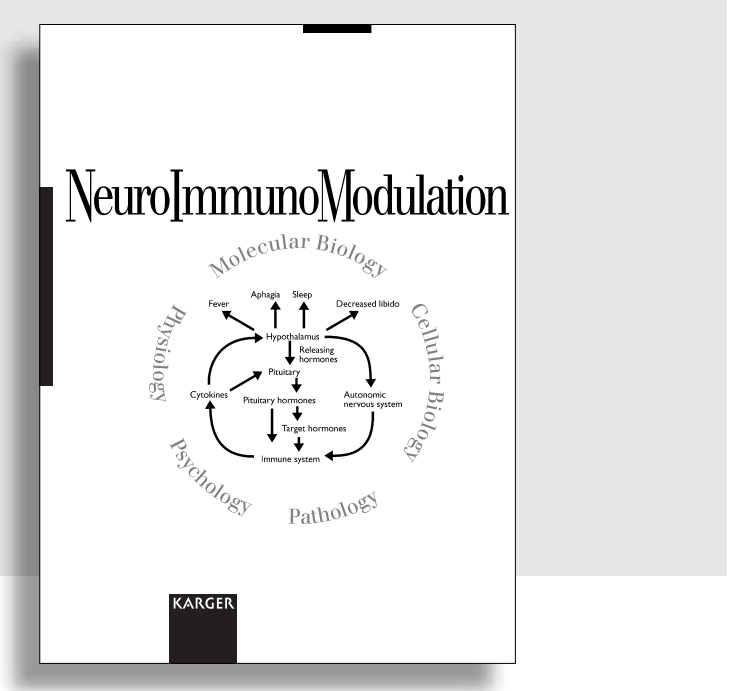

The rapidly expanding area of research known as neuroimmunomodulation explores the way in which the nervous system interacts with the immune system via neural, hormonal, and paracrine actions. Encompassing both basic and clinical research, Neuroimmunomodulation reports on all aspects of these interactions. Basic investigations consider all neural and humoral networks from molecular genetics through cell regulation to integrative systems of the body. The journal also aims to clarify the basic mechanisms involved in the pathogenesis of the CNS pathology in AIDS patients and in various neurodegenerative diseases. Although primarily devoted to research articles, timely reviews are published on a regular basis. To ensure high quality, all papers are reviewed by at least two referees, with every effort made to maintain a short publication time.

\section{Selected contributions}

Models of Aging of Neuroimmunomodulation: Strategies for Its Improvement: De la Fuente, M. (Madrid); Gimenez-Llort, L. (Bellaterra)

When Immune-Neuro-Endocrine Interactions Are Disrupted: Experimentally Induced Arthritis as an Example: del Rey, A. (Marburg); Wolff, C. (Regensburg): Wildmann, J.; Randolf, A. (Marburg); Straub, R.H. (Regensburg); Besedovsky, H.O. (Marburg)

Sympathetic Modulation of the Host Defense Response to Infectious Challenge during Recovery from Hemorrhage: Whitaker, A.M.; Sulzer, J.; Walker, E.; Mathis, K.; Molina, P.E. (New Orleans, La.)

Intravenous Immunoglobulin Reduces Infarct Volume but Not Edema Formation in Acute Stroke: Walberer, M. (Cologne); Nedelmann, M.; Ritschel, N. (Giessen/Nauheim); Mueller, C. (Nauheim); Tschernatsch, M. (Giessen); Stolz, E. (Giessen/Nauheim): Bachmann, G. (Nauheim); Blaes, F. (Giessen); Gerriets, T. (Giessen/Nauheim)

Expression of Activity-Dependent Neuroprotective Protein in the Immune System: Possible Functions and Relevance to Multiple Sclerosis: Braitch, M.; Kawabe, K.; Nyirenda, M.; Gilles, L.J.; Robins, R.A.; Gran, B. (Nottingham); Murphy, S. (Seattle, Wash.); Showe, L. (Philadelphia, Pa.); Constantinescu, C.S. (Nottingham)

Super-High-Dose Methylprednisolone Does Not Improve Efficacy or Induce Glucocorticoid Resistance in Experimental Allergic Encephalomyelitis: Wei, z.; Hong, M.; Su, Q.; Wang, X.; Yu, Q.; Peng, Z.; Zhang, M.; Jie, A.; Wang, R.; Huang, Y. (Guangzhou)

MPTP-Induced Neuroinflammation Increases the Expression of Pro-Inflammatory Cytokines and Their Receptors in Mouse Brain: Lofrumento, D.D. (Lecce); Saponaro, C.; Cianciulli, A. (Bari); De Nuccio, F. (Lecce); Mitolo, V. (Bari); Nicolardi, G. (Lecce); Panaro, M.A. (Bari)
More information at

\section{www.karger.com/nim}

- Pay-per-View and Subscriber Access to Full Text

- Full Table of Contents

- Full Editorial Board

- Free Abstracts and Selected Articles

- Online Sample Issue

- Submission/Guidelines for Authors

- Subscription Details

- Free Alert Service

- Online Library Recommendation

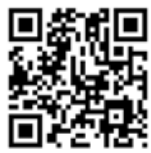

Neuroimmunomodulation

2012: Volume 19

6 issues per volume Language: English

ISSN 1021-7401 (print)

ISSN 1423-0216 (online)

Listed in bibliographic services, including Current Contents ${ }^{\circledR}$ MEDLINE, EMBASE/Excerpta Medica, Neuroscience Citation Index/Medline 


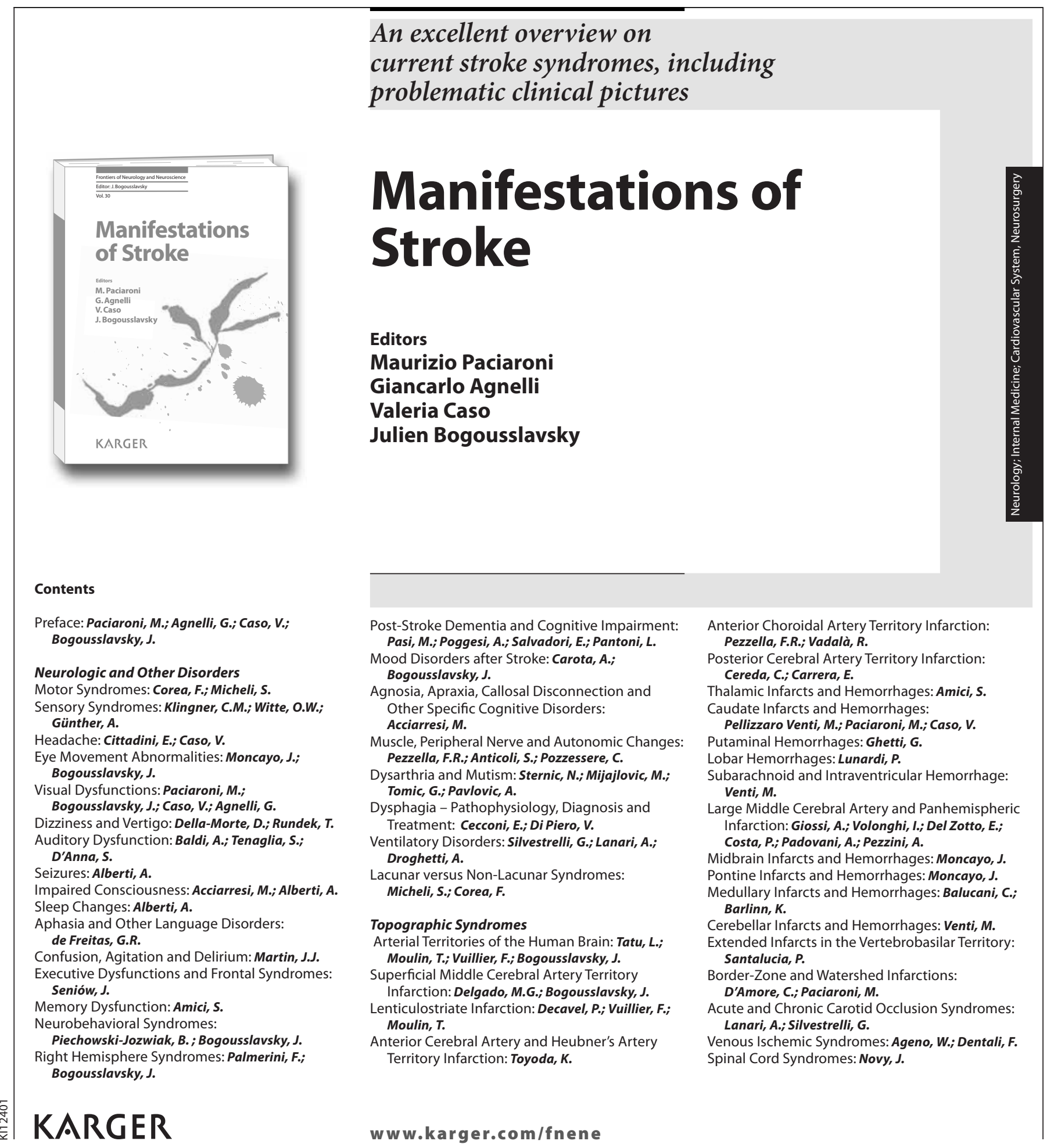

Frontiers of Neurology and Neuroscience, Vol. 30

Series Editor: Bogousslavsky, J. (Montreux)

ISSN 1660-4431 / e-ISSN 1662-2804

Manifestations of Stroke

Editors: Paciaroni, M.; Agnelli, G.; Caso, V. (Perugia);

Bogousslavsky, J. (Montreux)

$X+206$ p., 46 fig., 9 in color, 14 tab., hard cover, 2012

CHF 198.- / EUR 165.- / USD 233.00

Prices subject to change

EUR price for Germany, USD price for USA only

ISBN 978-3-8055-9910-8

e-ISBN 978-3-8055-9911-5

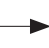

Please send

copy/ies

$\boldsymbol{\varepsilon}$

Postage and handling free with prepayment

Payment:

- Please charge to my credit card

- $\square$ American Express $\square$ Diners

ᄂ $\square$ MasterCard $\square$ Visa

- Card No.

(

ర Exp. date

- CVV/CVC

( 3 digits in the signature field on the back of Visa and MasterCard)

$\square$ Check enclosed $\quad \square$ Please bill me

Orders may be placed with any bookshop, subscription agency, directly with the publisher or through a Karger distributor.
Fax: +41 613061234

S. Karger AG, P.O. Box, CH-4009 Basel (Switzerland)

E-Mail orders@karger.ch,www.karger.com

Name/Address: 


\section{How current biomakers are modernizing \\ the diagnosis of Alzheimer's Disease}

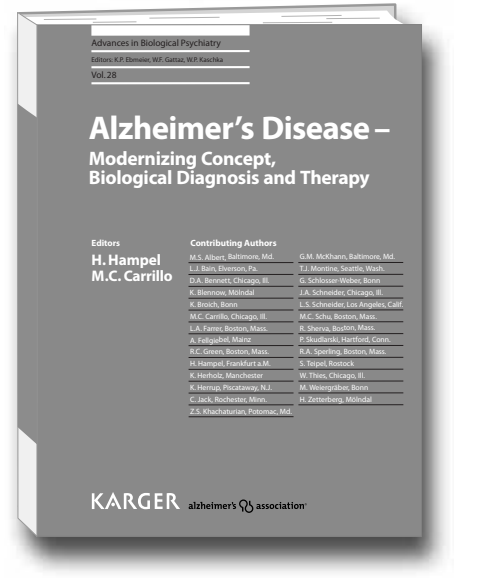

Expanding knowledge on genetic and epigenetic risk factors is rapidly enhancing our understanding of the complex molecular interactions and systems involved in the pathogenesis of Alzheimer's disease. In this publication, leading experts discuss emerging novel conceptual models of the disease along with advances in the development of surrogate markers that will not only improve the accuracy of diagnostic technologies but also improve the prospects of developing disease-modifying interventions. The novel framework of the disease presented here highlights research on biological markers as well as efforts to validate technologies for early and accurate detection. It also introduces notion of a complex systems dysfunction that extends beyond prevailing ideas derived from the 'amyloid' or 'tau' hypotheses.

This outstanding publication provides researchers, clinicians, students and other professionals interested in neurodegenerative disorders with a comprehensive update on current trends and future directions in therapy development, with special focus on advances in clinical trial designs.

\section{Alzheimer's Disease - Modernizing Concept, Biological Diagnosis and Therapy}

\author{
Editors \\ Harald Hampel \\ Maria C. Carrillo
}

\section{Contents}

The Global Impact of Alzheimer's Disease: Carrillo, M.C.; Thies, W.; Bain, L.J.

The Genetics of Alzheimer's Disease: Schu, M.C.; Sherva, R.; Farrer, L.A.; Green, R.C.

Current Conceptual View of Alzheimer's Disease: Herrup, $\boldsymbol{K}$.

Neuropathological Basis of Alzheimer's Disease and Alzheimer's Disease Diagnosis: Schneider, J.A.; Montine, T.J.; Sperling, R.A.; Bennett, D.A..

Diagnostic Tools: Fluid Biomarkers for Alzheimer's Disease: Zetterberg, $\boldsymbol{H}_{\text {.; }}$ Hampel, H.; Blennow, $K$
MRI- and PET-Based Imaging Markers for the Diagnosis of Alzheimer's Disease: Teipel, S.; Sperling, R.A.; Skudlarski, P.; Jack, C.; Hampel, H.; Fellgiebel, A.; Herholz, K.

Changing Diagnostic Concepts of Alzheimer's Disease: McKhann, G.M.; Albert, M.S.; Sperling, R.A.

Pharmacological Treatment of Alzheimer's Disease: Schneider, L.S.

Regulatory Requirements on Clinical Trials in Alzheimer's Disease: Broich, $\boldsymbol{K}$.; Schlosser-Weber, G.; Weiergräber, M.; Hampel, $\boldsymbol{H}$.

Perspectives on Alzheimer's Disease: Past, Present and Future: Khachaturian, Z.S.

\section{KARGER}

www.karger.com/adbip

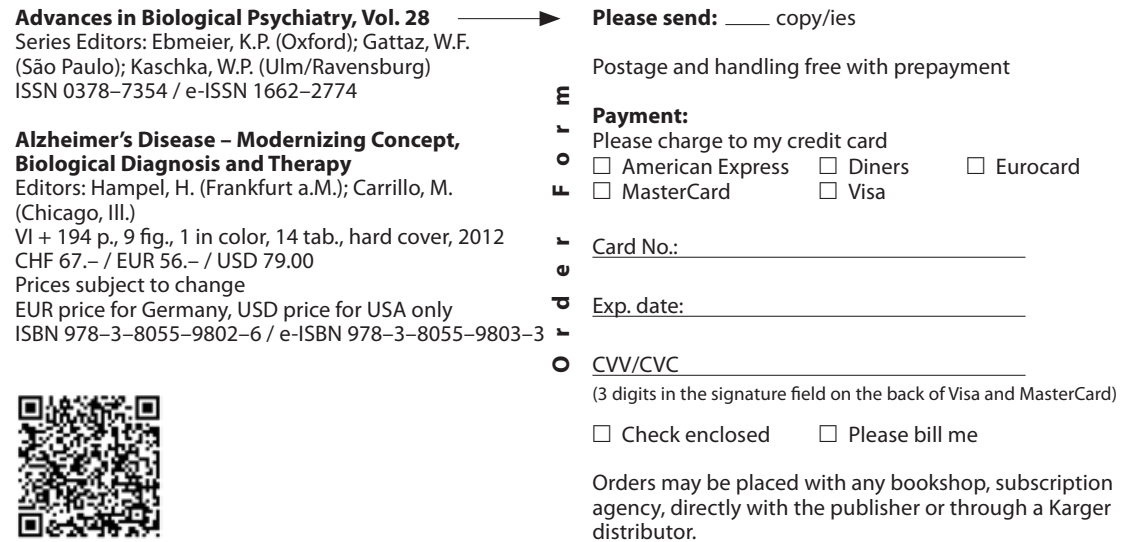

\section{Please send:}

copy/ies

Postage and handling free with prepayment

$\boldsymbol{\varepsilon}$

- Payment:

Please charge to my credit card

- $\square$ American Express $\square$ Diners $\square$ Eurocard

$\square$ Visa

- Card No

-

Exp.date:

- $\mathrm{CVV} / \mathrm{CVC}$

(3 digits in the signature field on the back of Visa and MasterCard)

$\square$ Check enclosed $\quad \square$ Please bill me

Orders may be placed with any bookshop, subscription agency, directly with the publisher or through a Karger distributor.
Fax: +41 613061234

S. Karger AG, P.O. Box, CH-4009 Basel (Switzerland) E-Mail orders@karger.ch, www.karger.com

Name/Address: 


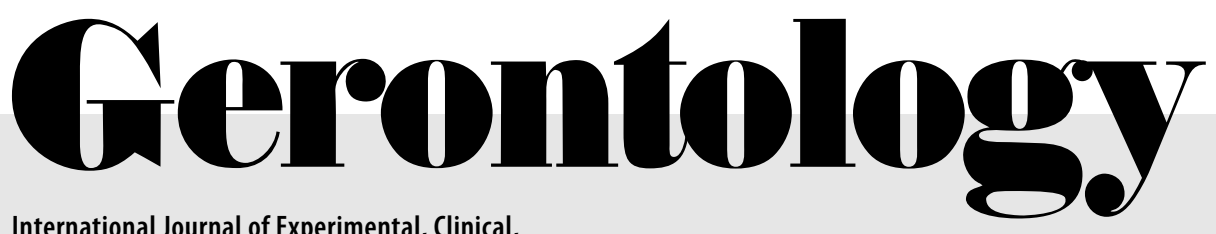

International Journal of Experimental, Clinical,

Behavioural, Regenerative and Technological Gerontology

Editor-in-Chief

G. Wick, Innsbruck

Organ of the International Association of Gerontology and Geriatrics (IAGG)

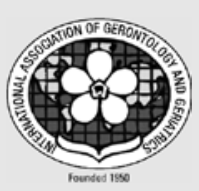

Section Editors

Clinical Section

M. Lechleitner, Zirl

\section{C.C. Sieber,}

Erlangen-Nürnberg

Experimental Section

A. Bartke, Springfield, III.

B. Friguet, Paris

Behavioural Science Section

M.A. Luszcz, Adelaide, S.A.

M. Martin, Zürich
Regenerative and Technological Section

G. Lepperdinger, Innsbruck (Regeneration)

M. Mokhtari, Singapore

(Technology)

Editor for the IAGG

M. Rodriguez Perracini, Sâo Paulo

\section{Gerontology}

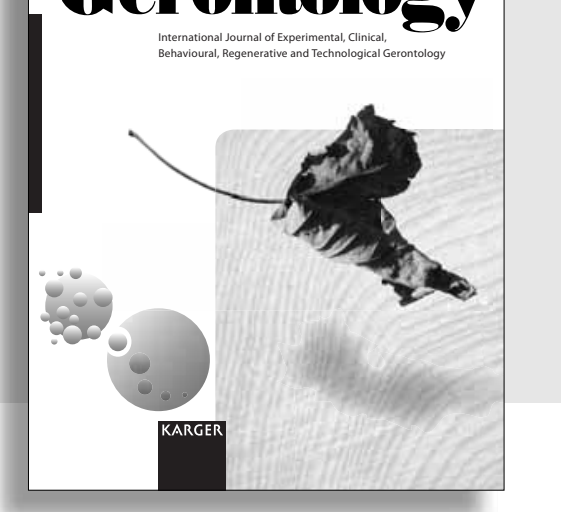

As the ratio of people over sixty-five continues to rise, understanding the basic mechanisms of aging and age-related diseases has become a matter of urgent necessity. Gerontology responds to this need by drawing topical contributions from diverse medical, biological, behavioural and technological disciplines. Recent research on the clinical problems of aging and the practical application of laboratory results are also included to support the fundamental goals of extending active life and enhancing its qual ity. Informative Mini-Reviews, Viewpoints as well as a critical Debate Section for stimulating, speculative articles carry strong reader approval. The Experimental Section contains contributions from basic gerontological research. Papers submitted for the Clinical Section discuss aetiology, pathogenesis, prevention and treatment of diseases in old age from a gerontological rather than a geriatric viewpoint. Papers dealing with behavioural development and related topics are published in the Behavioural Science Section. An extra Section covers research exploring basic aspects of regeneration in biological systems and regenerative medical approaches and deals with technological devices for the elderly. Providing a primary source of high-quality papers covering all aspects of aging in humans and animals, Gerontology serves as an ideal information tool for all readers interested in the topic of aging from a broad perspective.

\section{Selected contributions}

Science in Time of (risis: Schatz, G. (Basel)

Telomeres and Immunological Diseases of Aging: Andrews, N.P.; Fujii, H.; Goronzy, J.J.; Weyand, C.M. (Atlanta, Ga.)

Calorie Restriction and Dwarf Mice in Gerontological Research: Mckee Alderman, J.; DePetrillo, M.A.; Gluesenkamp, A.M.; Hartley, A.C.; Verhoff, S.V.; Zavodni, K.L.; Combs, T.P. (Chapel Hill, N.C.)

Sleep and Biomarkers of Atherosclerosis in Elderly Alzheimer Caregivers and Controls: von Känel, R. (Bern/La Jolla, Calif.); Ancoli-Israel, S.; Dimsdale, J.E.; Mills, P.J.; Mausbach, B.T.; Ziegler, M.G.; Patterson, T.L.; Grant, I. (La Jolla, Calif.)

Low Serum 1,25-Dihydroxyvitamin D Level and Risk of Respiratory Infections in Institutionalized Older People: Asamura, T.; Ohrui, T. (Sendai); Nakayama, K. (Tokyo); He, M.; Yamasaki, M.; Ebihara, T.; Ebihara, S.; Furukawa, K.; Arai, H. (Sendai)

Examination of the Common Cause Account in a Population-Based Longitudinal Study with Narrow Age Cohort Design: Sternäng, 0. (Stockholm); Jonsson, B. (Umea); Wahlin, Å. (Stockholm); Nyberg, L. (Umeå); Nilsson, L.-G. (Stockholm)

Disability and Depressive Symptoms in Later Life: The Stress-Buffering Role of Informal and Formal Support: Chan, N.; Anstey, K.J.; Windsor, T.D. (Canberra, A.C.T.); Luszcz, M.A. (Adelaide, S.A.)

Molecular Signaling Networks That Choreograph Epimorphic Fin Regeneration in Zebrafish - A Mini-Review: Tal, T.L.; Franzosa, J.A.; Tanguay, R.L. (Corvallis, Oreg.) Review of Wireless and Wearable Electroencephalogram Systems and BrainComputer Interfaces - A Mini-Review: Lin, C.-T.; Ko, L.-W.; Chang, M.-H. (Hsinchu); Duann, J.-R. (Hsinchu/San Diego, Calif.); Chen, J.-Y. (Hsinchu); Su, T.-P. (Hsinchu/Taipei); Jung, T.-P. (Hsinchu/San Diego, Calif.)
More information at

\section{www.karger.com/ger}

- Pay-per-view and Subscriber Access to Full Text

- Full Table of Contents

- Full Editorial Board

- Free Abstracts and Selected Articles

- Online Sample Issue

- Submission/Guidelines for Authors

- Subscription Details

- Free Alert Service

- Online Library Recommendation

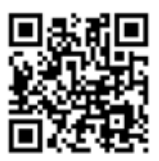

Gerontology

2012: Volume 58

6 issues per volume

Language: English

ISSN 0304-324X (print)

ISSN 1423-0003 (online) 


\section{A collection of extraordinary essays on key issues in the natural sciences}

\section{GOTTFRIED SCHATZ}
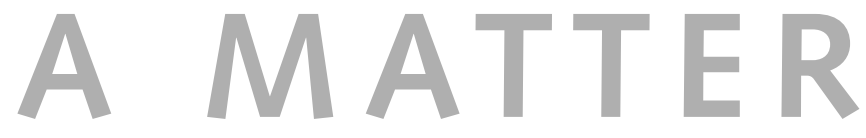

(
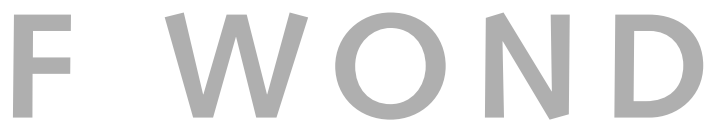

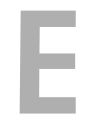

\section{WHAT BIOLOGY REVEALS ABOUT US, OUR WORLD, AND OUR DREAMS}

Where do we come from? Is our destiny determined by the genes we inherit? Do we all see the same blue color when we look at the sky? In this book Gottfried (Jeff) Schatz, the worldrenowned biochemist, gives lucid - albeit often surprising - answers to universal questions and takes the reader on a fascinating journey of discovery across the boundaries of scientific disciplines. With passion and a keen sense of wonder he draws on philosophy, cultural history and art to formulate his reflections on the mystery of life. The key to understanding life is to be found in its chemistry, and he proves that this is no dry endeavor and certainly not devoid of beauty. The result is a collection of eloquently and poetically written essays dealing with key issues in the natural sciences. It will appeal not only to scientists, but also to all inquisitive minds, regardless of educational and professional background.

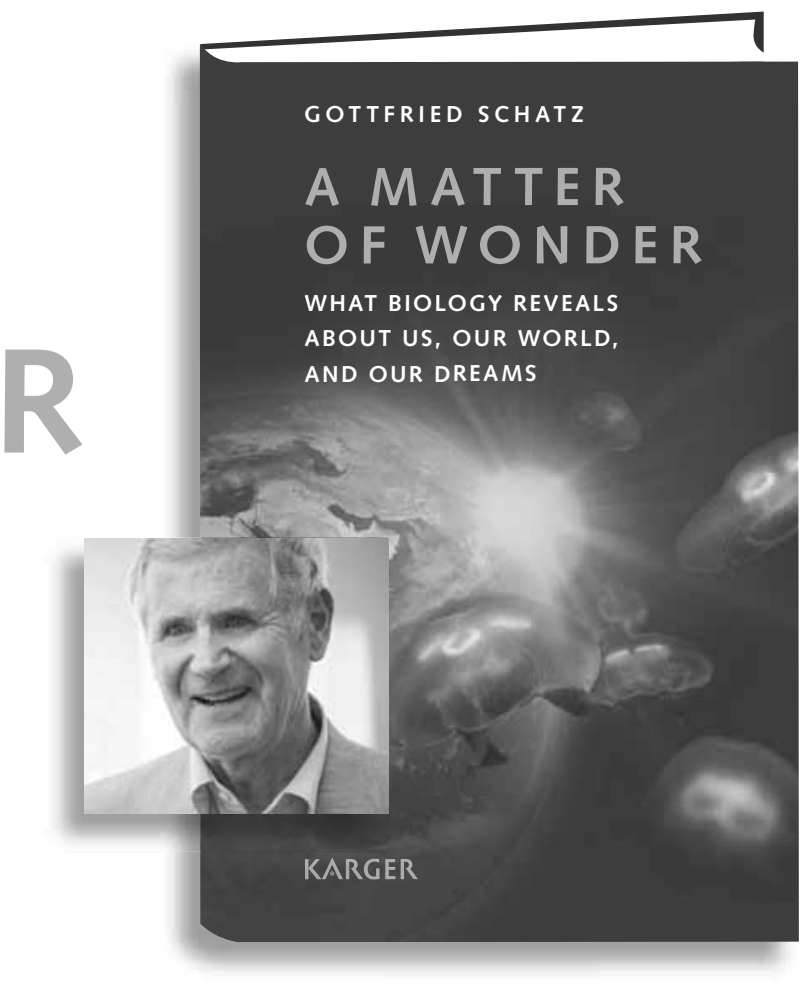

Schatz, G. (Basel)

A Matter of Wonder

What Biology Reveals about Us, Our World, and Our Dreams

XII + 190 p., 2 color fig., hard cover, 2011

CHF 29.- / EUR 21.50 / USD 29.00

Prices subject to change

EUR price for Germany, USD price for USA only

ISBN 978-3-8055-9744-9

More information and sample essays at

\section{www.karger.com/schatz}

Orders can be placed at agencies, bookstores or directly with the publisher.

Also available through Amazon.com.

\footnotetext{
6 A collection of extraordinary essays, reminiscent in many ways - scope, erudition, clarity, occasional whimsicality and sassiness - of Stephen Jay Gould's essays for Natural History? Herbert Deinert (Cornell University, Ithaca, N.Y.)
} 